\title{
Effect of delayed insemination on in-vitro fertilization, culture and transfer of human embryos
}

\author{
A. O. Trounson, Linda R. Mohr, C. Wood and J. F. Leeton \\ Department of Obstetrics and Gynaecology, Monash University, Queen Victoria Medical \\ Centre, 172 Lonsdale Street, Melbourne, Australia 3000
}

\begin{abstract}
Summary. Oocytes were obtained from patients with tubal infertility at fixed times after the onset of the endogenous LH rise or hCG injection, and were inseminated immediately after recovery or after periods of $4-4 \frac{1}{2}, 5-5 \frac{1}{2}$ and $6-6 \frac{1}{2} \mathrm{~h}$ in culture in vitro. Delayed insemination resulted in a marked increase in the proportion of oocytes that were fertilized and developed to normal embryos and maximum rates occurred after $5-5 \frac{1}{2} \mathrm{~h}$ in culture $\left(0-\frac{1}{2} \mathrm{~h}, 26 \% ; 4-4 \frac{1}{2} \mathrm{~h}, 50 \% ; 5-5 \frac{1}{2} \mathrm{~h}, 89 \% ; 6-6 \frac{1}{2} \mathrm{~h}\right.$, $69 \%$ ). The range and mean ( \pm s.d.) intervals from insemination for the pronuclear and early cleavage stages were $27-43(35.6 \pm 4.4) \mathrm{h}$ for 2-cell stages, 36-65 $(45 \cdot 7 \pm 8 \cdot 3) \mathrm{h}$ for 4 -cell stages, $45-73(54.3 \pm 12 \cdot 6) \mathrm{h}$ for 8-cell stages and $68-85 \mathrm{~h}$ for the 16-cell stage. In 7/50 patients receiving 1 or 2 embryos at the 2 -, 4 - and 8-cell stages, fetal development was normal and 2 women had twin pregnancies $(36 \%$ success compared with $8 \%$ for single embryos). All pregnancies were from the groups in which insemination was delayed for $5-6 \frac{1}{2} \mathrm{~h}$. It is concluded that a short period of culture in vitro may allow the completion of oocyte maturation, and improve the results of in-vitro fertilization.
\end{abstract}

\section{Introduction}

The process of fertilization of human oocytes by spermatozoa in vitro has been described in detail by a number of workers (Edwards, Bavister \& Steptoe, 1969; Bavister, Edwards \& Steptoe, 1969; Soupart \& Strong, 1974, 1975; McMaster, Yanagimachi \& Lopata, 1978; Lopata, Sathananthan, McBain, Johnston \& Speirs, 1980). The birth of normal babies following the transfer of 8- to 16-cell embryos to the uteri of women with blocked Fallopian tubes after fertilization in vitro (Edwards, Steptoe \& Purdy, 1980b) would support the proposition that, at least in some cases, normal fertilization can occur in vitro. However, the relatively low rate of success in establishing normal pregnancies after transfer of embryos to the uterus of the oocyte donor may be due, in part, to the failure of normal fertilization and embryonic development, because oocyte maturation is often incomplete at the time of insemination. Some evidence to support this hypothesis has been obtained from experiments in sheep (R. M. Moor, A. O. Trounson, S. M. Willadsen \& C. Polge, unpublished data). In these experiments, exposure of follicular oocytes to spermatozoa in vivo before oocyte maturation was complete resulted in the failure of normal fertilization and failure of, or abnormal, cleavage and embryonic development. Delay of insemination to allow the oocyte time to complete the maturation process within the oviduct resulted in a marked increase in the number of normal blastocysts. This observation led us to investigate the possibility that delayed insemination in vitro of human follicular oocytes, obtained at unknown and probably variable intervals from ovulation, may lead to an increase in normal fertilization, embryonic development and pregnancy after embryo transfer. 


\section{Materials and Methods}

\section{Subjects}

Oocytes were recovered from the ovaries of patients at laparoscopy by the methods described by Renou, Trounson, Wood \& Leeton (1981), Wood, Leeton, Talbot \& Trounson (1981a), and Wood et al. (1981b). In some patients the final maturation of oocytes was controlled by the intramuscular injection of 4000 i.u. hCG (Pregnyl; Organon Aust. Ltd, Clayton, Australia), and is termed the controlled ovulatory cycle. Alternatively, oocyte maturation was allowed to occur naturally and the time of oocyte recovery was determined from the time of the onset of the endogenous $\mathrm{LH}$ rise, and is termed the natural ovulatory cycle.

For controlled ovulation, all the patients were given $150 \mathrm{mg}$ clomiphene citrate (Clomid; S. Merrell and Co., Sydney, Australia) daily from Day 5 to Day 9 after the start of menses (Day 1). On Day 10, the patients were examined by ultrasonics to assess the size of ovarian follicles (Kratochwil, Urban \& Friedrich, 1972). If the largest follicle seen was $1.7 \mathrm{~cm}$ or larger in diameter, the patient was admitted to hospital and, if there was no endogenous LH surge, within 1 or 2 days given hCG $34-37$ h before laparoscopy, to correspond with available theatre lists (usually on Days 13 to 15). If the follicles were smaller than $1.6 \mathrm{~cm}$ in diameter, a second ultrasound examination was performed 2 days later. When no follicles were seen by ultrasound, the appearance of preovulatory cervical mucus changes (Trounson, Mahadevan, Wood \& Leeton, 1979) was used to determine the time of hCG injection.

Patients allocated to the natural ovulatory cycle were given clomiphene citrate, as described previously, or no treatment to stimulate follicular growth. The patients were examined by ultrasonics to assess follicular size on Days 10-12, and were admitted to hospital on the same criteria as for controlled ovulation. Urine samples were obtained from all patients every $3 \mathrm{~h}$ in hospital and $\mathrm{LH}$ excretion rate was determined by a commercial test (Higonavis: Mochida Pharmaceutical Co. Ltd, Tokyo, Japan) or radioimmunoassay (Trounson, Herreros, Burger \& Clarke, 1980a).

Laparoscopy was timed for $26-29 \mathrm{~h}$ after the mid-point in time of the first urine sample with elevated $\mathrm{LH}$ excretion rates (greater than twice the standard deviation of all previous baseline samples). Three consecutive samples with elevated $\mathrm{LH}$ were required before the rise was accepted as the genuine preovulatory surge and the time of laparoscopy confirmed.

\section{Insemination and oocyte culture}

Follicular fluid aspirates were examined immediately after collection in small disposable Petri dishes (Kayline Plastics, Thebarton, Australia) and the oocyte and cumulus mass were identified and washed in follicular fluid that was free of erythrocytes or washed in the culture medium used for insemination when uncontaminated follicular fluid was not available. The oocyte and cumulus mass was then transferred to $1 \mathrm{ml}$ culture medium for insemination in $5 \mathrm{ml}$ tissue-culture tubes (Falcon Plastics, Oxnard, California, U.S.A.). The tops of the tubes were covered with the caps provided but were not sealed, and they were incubated at $37.5^{\circ} \mathrm{C}$ in an humidified atmosphere of $5 \% \mathrm{CO}_{2}, 5 \% \mathrm{O}_{2}$ and $90 \% \mathrm{~N}_{2}$.

The culture medium used for insemination was modified Hams F10 or the mouse embryo culture medium described by Hoppe \& Pitts (1973), modified as described by Trounson, Leeton, Wood, Webb \& Kovacs (1980b). Hams F10 medium was prepared from the dried powder (Flow Laboratories, Sydney, Australia) using five times glass-distilled water and contained (per ml) $211 \mu \mathrm{g} \mathrm{NaHCO}_{3}, 5 \mathrm{mg}$ human serum albumin (Sigma Pharmaceuticals, Melbourne, Australia), $75 \mu \mathrm{g}$ penicillin $\mathrm{G}$ and $75 \mu \mathrm{g}$ streptomycin sulphate, with or without $245 \mu \mathrm{g}$ calcium lactate. The final osmolarity of the solution was adjusted to $280 \mathrm{mosmol}$ and a final pH of 7.4.

Semen samples were obtained in hospital from the husbands of the oocyte donors $1-2 \mathrm{~h}$ before insemination of the oocytes. The concentration, motility and proportion of live 
spermatozoa, as determined by the eosin $\mathrm{Y}$ dye exclusion test, were recorded. After liquefaction of the semen $\left(10-20 \mathrm{~min}\right.$ at $\left.35^{\circ} \mathrm{C}\right), 1 \mathrm{ml}$ semen was added to a $10 \mathrm{ml}$ tissue-culture tube containing $3 \mathrm{ml}$ of the medium for insemination, which had been equilibrated at $37.5^{\circ} \mathrm{C}$ under $5 \% \mathrm{CO}_{2}$ in air for at least $3 \mathrm{~h}$. The sperm suspension was thoroughly mixed by gentle pipetting and any gelatinous material or cellular aggregations were removed. The sample was then centrifuged for $10 \mathrm{~min}$ at $500 \mathrm{~g}$ and the supernatant discarded. The sperm pellet was re-suspended in $2 \mathrm{ml}$ culture medium by gentle pipetting and the larger cell aggregations again removed. The sample was re-centrifuged for $5 \mathrm{~min}$ and the supernatant discarded. The spermatozoa were then allowed to migrate into $0.2-1.0 \mathrm{ml}$ culture medium that was gently added to the surface of the sperm pellet, during incubation for $30-45 \mathrm{~min}$ at $37.5^{\circ} \mathrm{C}$ under $5 \%$ $\mathrm{CO}_{2}$ in air. The volume of culture medium added was in proportion to the concentration of motile spermatozoa in the fresh ejaculate so that the final concentration of spermatozoa for insemination was in the order of $45-100 \times 10^{6} / \mathrm{ml}$. An aliquot was then taken from the surface of the sample and transferred to a $5 \mathrm{ml}$ Falcon tube. The sperm concentration and motility were determined in the final sperm suspension and $0 \cdot 3-0.8 \times 10^{6}$ motile spermatozoa were added in a volume of $10-30 \mu$ to the culture tubes containing the oocytes.

In the present study, spermatozoa were added to the oocytes immediately after collection $(0-30 \mathrm{~min})$ or at $4-4 \frac{1}{2} \mathrm{~h}, 5-5 \frac{1}{2} \mathrm{~h}$ and $6-6 \frac{1}{2} \mathrm{~h}$ after collection of the oocytes.

The oocytes were taken out of the insemination medium $12-23 \mathrm{~h}$ after the addition of spermatozoa and the adhering cumulus cells were removed by gentle pipetting in a series of finely drawn pasteur pipettes. The internal diameters of these pipettes were chosen for the efficient removal of cumulus cells without distortion of the oocyte and in some instances 2 or 3 pipettes were used in order of decreasing bore size. The presence or absence of 2 distinct pronuclei and 1 or 2 polar bodies were noted. Any other abnormality such as multiple pronuclei, granulation or vesiculation of the cytoplasm or an abnormal shape of the oocyte were also recorded. This step of the procedure was carried out at room temperature $\left(22-24^{\circ} \mathrm{C}\right)$ in a Petri dish containing the culture medium used for embryonic development. The medium for culture differed from the medium used for insemination by the replacement of BSA or HSA with $15 \%(\mathrm{v} / \mathrm{v})$ heat-inactivated $\left(56^{\circ} \mathrm{C}\right.$ for $\left.30 \mathrm{~min}\right)$ serum obtained from the patient $1-2$ days before laparoscopy.

The cumulus-denuded oocyte was returned to incubation in $1 \mathrm{ml}$ serum-enriched medium for embryo culture in a $5 \mathrm{ml}$ tissue-culture tube which had been previously equilibrated for 8-16 h under $5 \% \mathrm{CO}_{2}, 5 \% \mathrm{O}_{2}$ and $90 \% \mathrm{~N}_{2}$ at $37.5^{\circ} \mathrm{C}$. The oocytes were examined in the culture tubes for cleavage once or twice every $24 \mathrm{~h}$ and the cleavage stage noted. Oocytes were fixed for examination by phase-contrast microscopy as whole mounts or were sectioned for transmission electron microscopy, if they failed to cleave within $24 \mathrm{~h}$ of removal of cumulus cells, if they underwent abnormal or uneven cleavage or fragmentation, or if they showed arrested cleavage for $24 \mathrm{~h}$ or more.

Embryos that cleaved regularly within each $24-\mathrm{h}$ period were considered to be normal if the blastomeres were of equal size. The normal embryos were transferred to the patient's uterine cavity in 10-25 $\mu$ culture medium in fine Teflon tubing (20-26 French gauge) or were frozen (A. Trounson, unpublished data).

\section{Results}

\section{Delayed insemination of oocytes}

The results of all attempted fertilizations in vitro of oocytes with dispersed or activated cumulus are shown in Table 1. There was no difference, overall or within intervals of delayed insemination, between patients given hCG and those in which the rise of endogenous LH was used to determine the time of oocyte recovery. There was a marked effect of the interval of 
delayed insemination on the proportion of oocytes with pronuclei that subsequently showed normal cleavage $\left(\chi_{3}^{2}=34.5 ; P<0.001\right)$. A delay of even $4-4 \frac{1}{2} \mathrm{~h}$ appeared to improve the proportion of fertilized oocytes, and this improvement could be clearly distinguished at $5-5 \frac{1}{2} \mathrm{~h}$ and $6-6 \frac{1}{2} \mathrm{~h}$ when more oocytes were involved. Maximum fertilization and cleavage rates occurred at $5-5 \frac{1}{2} \mathrm{~h}(89 \%$ of all activated oocytes cleaved normally) and the difference between $5-5 \frac{1}{2} \mathrm{~h}$ and $6-6 \frac{1}{2} \mathrm{~h}(69 \%)$ was significant $\left(\left(\chi_{1}^{2}=4 \cdot 36 ; P<0.05\right)\right.$.

Table 1. The influence of delayed insemination on fertilization and cleavage of human oocytes in vitro

\begin{tabular}{|c|c|c|c|c|c|c|}
\hline \multirow[b]{2}{*}{$\begin{array}{c}\text { Interval } \\
\text { between oocyte } \\
\text { collection and } \\
\text { insemination (h) }\end{array}$} & \multirow[b]{2}{*}{$\begin{array}{c}\text { Type of } \\
\text { ovulatory } \\
\text { control }\end{array}$} & \multirow[b]{2}{*}{$\begin{array}{c}\text { No. } \\
\text { of } \\
\text { patients }\end{array}$} & \multicolumn{4}{|c|}{ No. of oocytes } \\
\hline & & & $\begin{array}{c}\text { With } \\
\text { activated } \\
\text { cumulus }\end{array}$ & $\begin{array}{c}\text { No } \\
\text { pronuclei }\end{array}$ & $\begin{array}{c}\text { Pronuclear } \\
(>2 \\
\text { pronuclei) }\end{array}$ & $\begin{array}{c}\text { Normal } \\
\text { cleavage (\% } \\
\text { of activated } \\
\text { oocytes) }\end{array}$ \\
\hline \multirow[t]{3}{*}{$0-\frac{1}{2}$} & Endogenous & 15 & 15 & 8 & $7(2)$ & $3(20)$ \\
\hline & hCG & 21 & 27 & 14 & $13(4)$ & $8(30)$ \\
\hline & Total & 36 & 42 & 22 & $20(6)$ & $11(26)$ \\
\hline \multirow[t]{3}{*}{$4-4 \frac{1}{2}$} & $\begin{array}{c}\text { Endogenous } \\
\text { LH }\end{array}$ & 2 & 2 & 0 & 2 & $1(50)$ \\
\hline & hCG & 2 & 2 & 1 & 1 & $1(50)$ \\
\hline & Total & 4 & 4 & 1 & 3 & $2(50)$ \\
\hline \multirow[t]{3}{*}{$5-5 \frac{1}{2}$} & $\begin{array}{c}\text { Endogenous } \\
\text { LH }\end{array}$ & 14 & 17 & 0 & 17 & $17(100)$ \\
\hline & hCG & 11 & 20 & 3 & 17 & $16(80)$ \\
\hline & Total & 25 & 37 & 3 & 34 & $33(89)$ \\
\hline \multirow[t]{3}{*}{$6-6 \frac{1}{2}$} & $\begin{array}{c}\text { Endogenous } \\
\text { LH }\end{array}$ & 11 & 16 & 3 & $13(1)$ & $12(75)$ \\
\hline & $\mathrm{hCG}$ & 14 & 20 & 5 & $15(1)$ & $13(65)$ \\
\hline & Total & 25 & 36 & 8 & $28(2)$ & $25(69)$ \\
\hline
\end{tabular}

Multiple pronuclei, which in at least two cases could be identified as polyspermia by the presence of sperm tails in the cytoplasm, occurred only in the oocytes inseminated immediately after recovery (6/20 (30\%) pronuclear oocytes) and in those in which insemination was delayed for $6-6 \frac{1}{2} \mathrm{~h}(2 / 28(7 \%)$ pronuclear oocytes). Abnormal cleavage or fragmentation was frequently associated with multiple pronuclei (Table 1) but the incidence in oocytes with two pronuclei was low throughout the groups $\left(3 / 14\right.$ at $0-\frac{1}{2} \mathrm{~h}, 1 / 3$ at $4-4 \frac{1}{2} \mathrm{~h}, 1 / 34$ at $5-5 \frac{1}{2} \mathrm{~h}$ and $1 / 26$ at $\left.6-6 \frac{1}{2} \mathrm{~h}\right)$.

\section{Cleavage and development of embryos}

The observations recorded for apparently normal cleavage in relation to the time after insemination are shown in Text-fig. 1. In many cases, cleavage at the 2-cell stage was not observed because of the interval between observations, and in some cases two observations were made at the 4-cell stage because of the necessity to transfer embryos. All embryos continued normal cleavage to the next stage or were transferred, and those with arrested development or that were abnormal are not included in the data used for Text-fig. 1. At the 1-cell stage (12-31 h after insemination), all the oocytes had two visible pronuclei and often two identifiable polar bodies. The earliest time normal 2-cell embryos were observed was $27 \mathrm{~h}$ after insemination and the latest time was $43 \mathrm{~h}$ (mean \pm s.d. time from insemination was $35.6 \pm 4.4$ h); 4-cell embryos were observed between 36 and $65 \mathrm{~h}$ (mean $45.7 \pm 8.3 \mathrm{~h}$ ), 8-cell embryos between 45 and $73 \mathrm{~h}$ (mean $54.3 \pm 12.6 \mathrm{~h}$ ) and 16-cell embryos between 68 and $85 \mathrm{~h}$. 


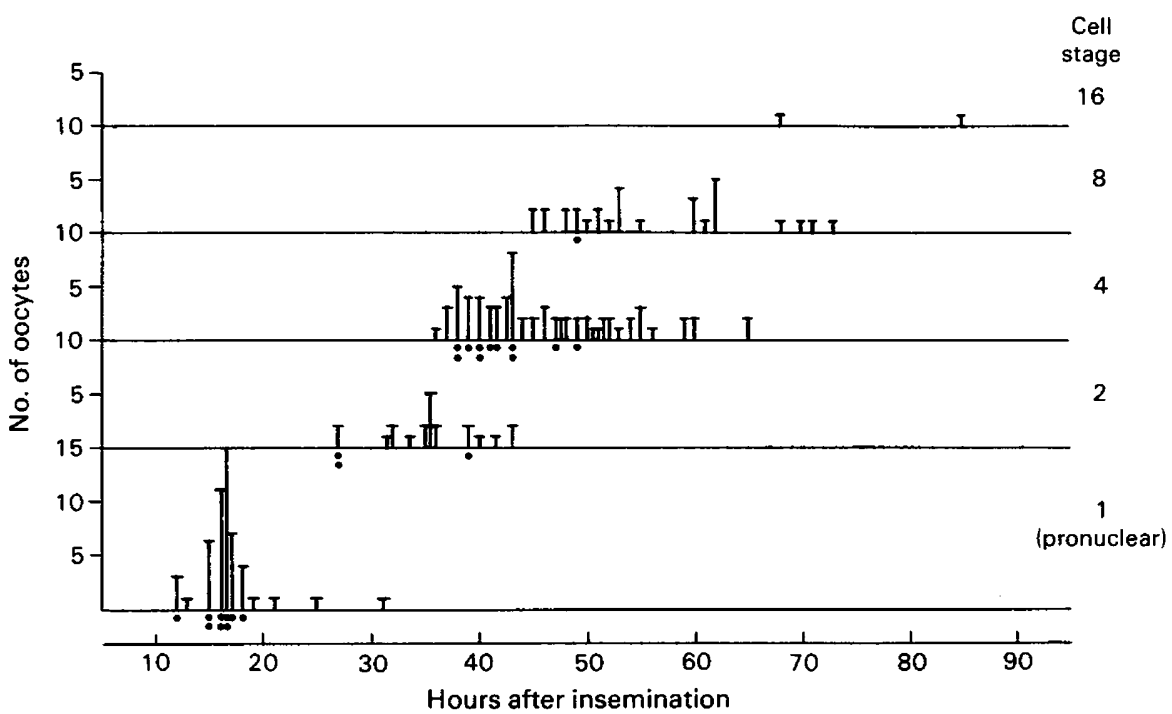

Text-fig. 1. Observations of the time after insemination and the developmental stages of oocytes and embryos which continued to cleave in vitro or were transferred to the patients. The vertical bars indicate the total number of oocytes or embryos within cleavage stages, recorded from observations made each day to assess progressive development of the embryos. The dots are all observations of the 9 oocytes and embryos which developed to fetuses after transfer to the patients.

The cleavage rates of the embryos that resulted in pregnancy after transfer to the patient show the minimum range over which normal cleavage may occur (Text-fig. 1). There was a considerable overlap in the time after insemination between each cleavage stage. This overlap was minimal in embryos that continued development to fetuses after transfer and there was a general trend for shorter cleavage intervals for these embryos. Embryos with the longer interval between cleavage divisions may have reduced viability and they may be more likely to become arrested as development continues.

Embryos developed equally well in the two types of culture media used and there were no apparent differences in the proportion of embryos developing, cleavage rate, or the final cell stage achieved. There was no difference in the cleavage rate of embryos from the different intervals of delayed insemination, which would indicate that if fertilization and cleavage is initiated it may proceed normally, under the culture conditions described in this paper, irrespective of when the spermatozoa are added to the oocyte.

In other investigations more advanced embryos have been obtained by culture in both the media described and the morphological appearance of human embryos at the various stages of development are shown in Plate 1. In the human embryo, the blastomeres remain separate until after the 16-cell stage. Compaction of the blastomeres occurs between 96 and $120 \mathrm{~h}$ at the morula stage of 32-cells or more and a blastocoele is visible between 120 and $144 \mathrm{~h}$. Fully expanded blastocysts and those hatched from the zona pellucida are obtained between 140 and $160 \mathrm{~h}$. Complete development from the pronuclear stage to the hatched blastocyst stage may be achieved in the one culture tube without change or addition of fresh culture medium.

\section{Development of embryos after transfer to the patients}

The successful establishment of fetuses, as seen by ultrasonics at a minimum of 8 weeks gestation and normal $\beta-h C G$ plasma levels, was confined to the groups in which insemination 


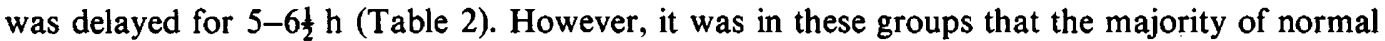
embryos was obtained and, consequently, the larger number of embryos transferred. Fetal development resulted from the transfer of 2-, 4- and 8-cell embryos, all of which appeared to be normal, with blastomeres of equal size and within the post-insemination interval expected for that cleavage stage (Text-fig. 1), although the one 2-cell embryo transferred together with a 4-cell embryo, $39 \mathrm{~h}$ after insemination, was considered to be close to the limit for cleavage from 2 - to 4- cells.

Table 2. Data on the delay in insemination, stage of embryo development, number of embryos transferred and number of pregnancies in women

\begin{tabular}{|c|c|c|c|c|c|c|}
\hline \multirow{2}{*}{$\begin{array}{c}\text { Interval of } \\
\text { delayed } \\
\text { insemination (h) }\end{array}$} & & \multirow{2}{*}{$\begin{array}{l}\text { No of } \\
\text { patients } \\
\text { receiving } \\
\text { embryos }\end{array}$} & \multirow{2}{*}{$\begin{array}{l}\text { Cell stage } \\
\text { of embryo }\end{array}$} & \multirow{2}{*}{$\begin{array}{l}\text { No. of embryos } \\
\text { transferred } \\
\text { to each patient }\end{array}$} & \multicolumn{2}{|c|}{ No. of pregnancies } \\
\hline & & & & & Single fetus & Twin fetuses \\
\hline \multirow[t]{4}{*}{$0-\frac{1}{2}$} & & 3 & 4-cell & 1 & 0 & - \\
\hline & & 4 & 8 -cell & 1 & 0 & - \\
\hline & & 1 & 16-cell & 1 & 0 & - \\
\hline & Total & 8 & & 8 & 0 & - \\
\hline \multirow[t]{2}{*}{$4-4 \frac{1}{2}$} & & 2 & 4-cell & 1 & 0 & - \\
\hline & Total & 2 & & 2 & 0 & - \\
\hline \multirow[t]{8}{*}{$5-5 \frac{1}{2}$} & & 1 & 2-cell & 1 & 0 & - \\
\hline & & $i$ & 2- and 4-cell & 2 & 0 & 1 \\
\hline & & 7 & 4-cell & 1 & 0 & - \\
\hline & & 4 & 4-cell & 2 & 2 & 1 \\
\hline & & 2 & 4- and 8-cell & 2 & 0 & 0 \\
\hline & & 5 & 8-cell & 1 & 0 & - \\
\hline & & 2 & 8-cell & 2 & 0 & 0 \\
\hline & Total & 22 & & 31 & 2 & 2 \\
\hline \multirow[t]{6}{*}{$6-6 \frac{1}{2}$} & & 1 & 2-cell & 1 & 0 & - \\
\hline & & 9 & 4-cell & 1 & 2 & - \\
\hline & & 2 & 4-cell & 2 & 0 & 0 \\
\hline & & 3 & 8-cell & 1 & 0 & - \\
\hline & & 3 & 8-cell & 2 & 1 & 0 \\
\hline & Total & 18 & & 23 & 3 & 0 \\
\hline
\end{tabular}

Considering only the groups in which insemination was delayed for 5-6 $\frac{1}{2} \mathrm{~h}, 2$ pregnancies resulted from the transfer of 26 single embryos, whereas 5 pregnancies resulted from the transfer of 14 twin embryos (Table 2). Two of the latter were diagnosed as twin fetuses. Overall, this represents a pregnancy rate of $36 \%$ and an embryo survival rate of $25 \%$ for twin embryos

\section{PLATE 1}

Developmental stages of human embryos. Photographs were taken during culture or before transfer of fresh unmounted specimens.

Fig. 1. A pronuclear-stage oocyte $16 \mathrm{~h}$ after insemination.

Fig. 2. A 2-cell embryo.

Fig. 3. A 4-cell embryo.

Fig. 4. An 8-cell embryo.

Fig. 5. A morula-stage embryo.

Fig. 6. A blastocyst which has hatched out of the zona pellucida. 
PLATE 1
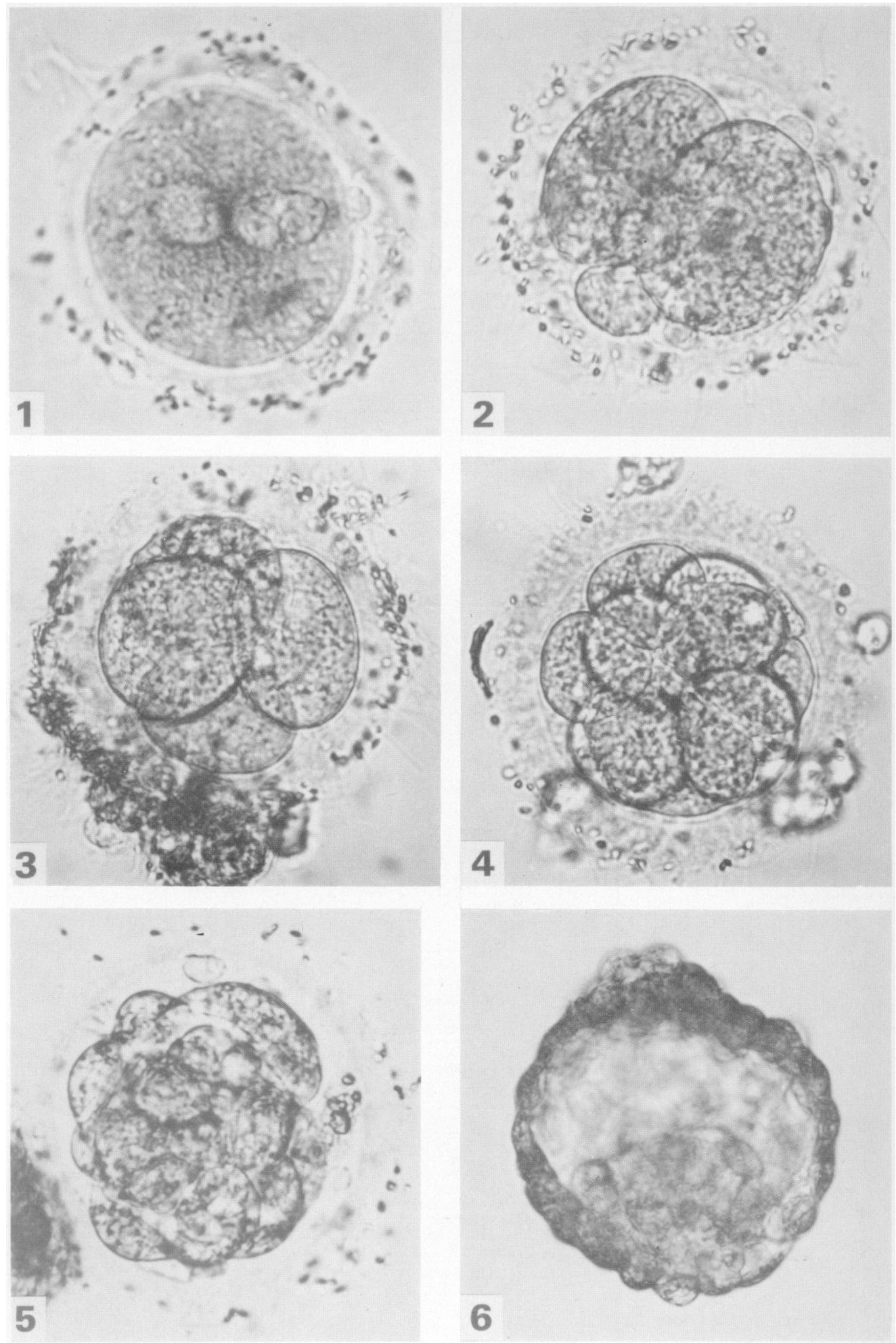
transferred, compared to $8 \%$ pregnancy and embryo survival rate for single embryos. The oocytes eventually leading to successful pregnancies were all from clomiphene-treated patients, 5 of which had also been given hCG injections.

\section{Discussion}

The recovery of follicular oocytes at fixed time intervals from arbitrary markers, such as the elevation of L.H excretion or the injection of hCG, must result in a variation in the stage of oocyte maturation achieved. Oocytes are rarely obtained from ovulated follicles of women (Wood et al., 1981a), and there is very little chance that ovulated oocytes could be recovered from tubal remnants by laparoscopy. To achieve the desired result of mature oocytes for in-vitro fertilization and embryo transfer, it was considered necessary to approach as close as possible the time of ovulation. In our studies we have found considerable variation in the proportion of patients with recent ovulations over the interval of 32-40 h after hCG injection and $24-30 \mathrm{~h}$ after detection of the endogenous LH rise. These proportions tend to approach the expected normal distribution. The use of clomiphene to induce the growth of multiple follicles (Trounson, Leeton, Wood, Webb \& Wood, 1981) enables laparoscopy to be carried out closer to the expected time of ovulation, as all follicles do not ovulate at exactly the same time and oocytes may be obtained from unruptured follicles even if ovulation has begun. Intervals of 35-36 h between hCG injection and laparoscopy and 26-27 h between the start of the LH surge and laparoscopy have been chosen in our work to minimize the occurrence of ovulation and to retain high rates of fertilization and development in vitro. As shown in the present studies, this can only be achieved if oocytes are cultured for $5-6 \frac{1}{2} \mathrm{~h}$ in vitro before insemination to allow oocyte maturation to be completed.

It is not possible to ascertain whether oocytes are completely mature at the time of recovery and there is no indicator, that may be measured in vivo, of the state of oocyte maturation following the $\mathrm{LH}$ stimulus. Even if it was assumed that there is a constant interval from the time the follicle receives the LH stimulus for the completion of oocyte maturation and ovulation, errors in determining the onset of the $\mathrm{LH}$ rise and the specific level of $\mathrm{LH}$ the follicles respond to would contribute to variation in stage of oocyte maturation at laparoscopy. In the natural ovulatory cycle there is frequently a lack of a sustained and easily distinguished LH surge with the assays that are currently being used. In preliminary experiments (Trounson et al., 1980a) we have shown that the rise in peripheral plasma progesterone concentrations is a more precise indicator for determining the time of laparoscopy for successful in-vitro fertilizations when no delay of insemination was used. It is known that progesterone secretion occurs in response to LH stimulation only in healthy follicles late in the follicular phase in woman (Baird, Baker, McNatty \& Neal, 1975; McNatty, Moore-Smith, Osathanondh \& Ryan, 1979; BomselHelmreich et al., 1979) and the determination of the onset of sustained progesterone secretion may be a better indicator of the time of ovulation and the time of oocyte maturity. The ovarian steroids, particularly oestrogen and progesterone, are intimately involved in the initiation of cytoplasmic maturation and in the final stage of nuclear maturation of oocytes (Thibault, 1977; Moor, 1978) and the importance of maintaining oestrogen levels in follicular fluid during oocyte maturation has been emphasized by McNatty, Moore-Smith, Makris, Osathanondh \& Ryan (1979) in follicles cultured in vitro and by Edwards, Steptoe, Fowler \& Baillie (1980a) in follicular aspirates of oocytes fertilized in vitro. Hunter, Cook \& Baker (1976) showed that pig oocytes, induced to ovulate with hCG when follicular oestrogens are low, fail to undergo normal nuclear and cytoplasmic maturation and, consequently, abnormalities of fertilization occur. In studies of the maturation of sheep oocytes cultured within follicles in vitro, Moor \& Trounson (1977) found that normal fertilization and embryonic development required the addition of both oestrogen and gonadotrophins to the culture media. In the controlled human ovulatory cycle, the 
injection of hCG does give some precision to the time that follicles are exposed to the stimulus for the resumption of meiosis. However, this does not greatly increase the synchronization of ovulation and this is probably related to variation in the capacity of follicles to bind and respond to hCG. We have noted that patients often ovulate before laparoscopy at $35 \mathrm{~h}$ if endogenous $\mathrm{LH}$ begins to rise at the time of hCG injection. Conversely, if hCG is given when follicles are smaller than $1.7 \mathrm{~cm}$ diameter or before urinary oestrogen excretion rates reach maximum levels (A. $O$. Trounson, unpublished data), follicles do not have the usual preovulatory appearance (Wood et al., 1981a) at laparoscopy and fertilization usually fails to occur. It is therefore important to administer hCG close to the time when the endogenous LH rise would normally occur and at a time when follicles are producing high levels of oestrogen. At present, the time of hCG injection is determined by the day of the menstrual cycle, follicle size, cervical mucus changes and daily urine or plasma oestrogen levels. When using these features to determine the time of hCG injection, some follicles may be still in the growth stage when they receive the LH stimulus, leading to differences in the time taken to initiate and complete the changes required for nuclear, cytoplasmic and membrane maturation of oocytes necessary for normal fertilization and development (Moor \& Warnes, 1979; Masui \& Clarke, 1979).

The occurrence of polyspermy observed at a relatively high incidence after insemination immediately after recovery when compared to delayed insemination could be attributed to the failure of complete cortical granule release after penetration by a spermatozoon. Cortical granules are often still migrating to the surface of the plasma membrane immediately after oocyte recovery and they accumulate under the membrane during $6 \mathrm{~h}$ of culture in vitro (A. H. Sathananthan \& A. O. Trounson, unpublished data). Close association of cortical granules with the plasma membrane is considered important for cortical granule release and the zona reaction (Millonig, 1969; Longo, 1973). Complete failure of sperm penetration of human oocytes may be due to changes in the zona which occur during maturation and alter its penetrability. Some support for this proposition is the failure of spermatozoa to penetrate into the ooplasm of immature oocytes obtained from follicles without prior culture in vitro (Overstreet \& Hembree, 1976). Soupart \& Morgenstern (1973) reported that penetration of spermatozoa through the zona was not related to the state of nuclear maturation in oocytes cultured for 38 to $48 \mathrm{~h}$, although fertilization occurred in only one oocyte with an immature nucleus. Edwards et al. (1969) also provided evidence of sperm penetration of the zona and fertilization of oocytes cultured for $38 \mathrm{~h}$ in vitro, but this was again confined to oocytes in which nuclear maturation was complete. Changes in the zona which allow penetration by spermatozoa may precede the completion of cortical granule migration to the plasma membrane, leading to polyspermy.

The relatively low incidence of gross abnormalities of cleavage of pronuclear oocytes could be due to the short period of culture used in the present studies. In other experiments, a varied proportion, $40-50 \%$ of regularly cleaving embryos, undergo fragmentation or arrested development beyond the 8-cell stage. The remainder of the embryos will continue development to at least the morula and hatched blastocyst stage. It is difficult to separate the effects of sub-optimal culture conditions during extended culture and potential embryonic abnormalities induced by collection of incompletely matured oocytes and fertilization in vitro. Fragmentation, retarded development and abnormal cleavage are common sequelae of the attempted fertilization of immature oocytes and oocytes matured by culture in vitro (Trounson, Willadsen \& Rowson, 1977; Moor \& Warnes, 1978).

The interval between cleavage divisions observed in the present study was similar to that reported by Edwards (1973) for in-vitro fertilized human embryos and for early cleavage divisions of mouse embryos (Whitten \& Dagg, 1961). In contrast to most species except for the mouse, the human embryo can be successfully cultured from the 1-cell stage to the hatched blastocyst stage in vitro (Steptoe, Edwards \& Purdy, 1971). Development beyond the 8-cell stage was confined to culture in Hams F10 medium in studies reported by Edwards (1973). Modified Earle's solution was used to obtain one of the successful pregnancies reported by 
Edwards et al. (1980b) and in more recent studies in our laboratory, blastocysts and pregnancies have been obtained from fertilization and culture in simple media used routinely for culture of mouse embryos (Trounson et al., 1980b). A simple culture medium with relatively few chemical components has the advantage of ensuring quality control, as there is less chance of introducing unsuitable chemicals at the time of preparation, and can be readily prepared in the laboratory.

The pregnancy rate obtained after embryo transfer in the present study is not entirely satisfactory for routine clinical use in the treatment of infertility, although the results continue to improve as procedures are optimized. The transfer of two embryos instead of a single embryo should result in a higher overall pregnancy rate if all the embryos have an equal potential for survival. This appeared to be the case with the limited numbers involved in the present study ( $36 \%$ for twin embryos and $8 \%$ for single embryos). There was no marked difference in the survival rate of embryos of different stages (2-cell to 16-cell) after transfer. This may be complicated by an interaction of reduced viability of embryos cultured for increasing periods of time and reduced embryonic survival due to premature transfer of early cleavage stage embryos, particularly 2- and 4-cell stages, to the uterus (see Adams, 1979). Before the 8-cell stage, human embryos are confined to the oviducts in vivo (Croxatto, Ortiz, Diaz \& Hess, 1979). Improved culture media and techniques and survival rates of different cleavage stage embryos are presently being investigated to determine the optimum procedures for maximum pregnancy rates.

In conclusion, it would appear that a relatively short period of culture in vitro following recovery of human follicular oocytes is beneficial for the completion of oocyte maturation and to allow for high rates of fertilization and embryonic development in vitro. This procedure overcomes the present deficiencies of predicting the exact time of ovulation and results in the production of at least a proportion of normal embryos that have the capacity for normal fetal development.

We thank the Ford Foundation and National Health and Medical Research Council of Australia, for financial support and J. Webb, D. Jessup, J. Wood, C. Caro, Dr B. Buttery, Dr J. M. Talbot and Dr G. Kovacs for their support and assistance.

\section{References}

Adams, C.E. (1979) Consequences of accelerated ovum transport, including a re-evaluation of Estes' operation. J. Reprod. Fert. 55, 239-246.

Baird, D.T., Baker, T.G., McNatty, K.P. \& Neal, P. (1975) Relationship between the secretion of the corpus luteum and the length of the follicular phase in the ovarian cycle. J. Reprod. Fert. 45, 611-619.

Bavister, B.D., Edwards, R.G. \& Steptoe, P.C. (1969) Identification of the midpiece and tail of the spermatozoon during fertilization of human eggs in vitro. J. Reprod. Fert. 20, 159-160.

Bomsel-Helmreich, O., Gougeon, A., Thebault, A., Saltarelli, D., Milgrom, E., Frydman, R. \& Papiernik, E. (1979) Healthy and atretic human follicles in the preovulatory phase: differences in evolution of follicular morphology and steroid content of follicular fluid. J. clin. Endocr. Metab. 48, 686-694.

Croxatto, H.B., Ortiz, M.E., Diaz, S. \& Hess, R. (1979) Attempts to modify ovum transport in woman. $J$. Reprod. Fert. 55, 231-237.

Edwards, R.G. (1973) Physiological aspects of human ovulation, fertilization and cleavage. J. Reprod. Fert., Suppl. 18, 87-101.
Edwards, R.G., Bavister, B.D. \& Steptoe, P.C. (1969) Early stages of fertilization in vitro of human oocytes matured in vitro. Nature, Lond. 221, 632-635.

Edwards, R.G., Steptoe, P.C., Fowler, R.E. \& Baillie, J. (1980a) Observations on preovulatory human ovarian follicles and their aspirates. Br.J. Obstet. Gynaec. 87, $769-779$.

Edwards, R.G., Steptoe, P.C. \& Purdy, J.M. (1980b) Establishing full-term human pregnancies using cleaving embryos grown in vitro. Br. J. Obstet. Gynaec. 87, 737-756.

Hoppe, P.C. \& Pitts, S. (1973) Fertilization in vitro and development of mouse ova. Biol. Reprod. 8, 420426.

Hunter, R.H.F., Cook, B. \& Baker, T.G. (1976) Dissociation of response to injected gonadotrophin between the Graafian follicle and oocyte in pigs. Nature, Lond. 260, 156-158.

Kratochwil, A., Urban, G. \& Friedrich, F. (1972) Ultrasonic tomography of the ovaries. Ann. Chir. Gynaecol. Fenniae. 61, 211-214.

Lawson, R.A.S., Rowson, L.E.A., Moor, R.M. \& Tervit, H.R. (1975) Experiments on egg transfer in the cow 
and ewe: dependance of conception rate on the transfer procedure and stage of the oestrous cycle. $J$. Reprod. Fert. 45, 101-107.

Longo, F.J. (1973) Fertilization: a comparative ultrastructural review. Biol. Reprod. 9, 149-215.

Lopata, A., Sathananthan, A.H., McBain, J.C., Johnston, W.I.H. \& Speirs, A.L. (1980) The ultrastructure of the preovulatory human egg fertilized in vitro. Fert. Steril. 33, 12-20.

McMaster, R., Yanagimachi, R. \& Lopata, A. (1978) Penetration of human eggs by human sperm in vitro. Biol. Reprod. 19, 212-216.

McNatty, K.P., Moore-Smith, D., Osathanondh, R. \& Ryan, K.J. (1979) The human antral follicle: functional correlates of growth and atresia. Annls Biol. Anim. Biochim. Biophys. 19, 1547-1558.

MeNatty, K.P., Moore-Smith, D., Makris, A., Osathanondh, R. \& Ryan, K.J. (1979) The microenvironment of the human antral follicle: interrelationships among the steroid levels in antral fluid, the population of granulosa cells, and the status of the oocyte in vivo and in vitro. J. clin. Endocr. Metab. 49, 851-860.

Masui, Y. \& Clarke, H.J. (1979) Oocyte maturation. Int. Rev. Cytol. 57, 185-282.

Millonig, G. (1969) Fine structure of the cortical reaction in sea urchin eggs: after normal fertilization and after electrical induction. J. Submicrosc. Cytol. 1, 69-84.

Moor, R.M. (1978) Role of steroids in the maturation of ovine oocytes. Annls Biol. Anim. Biochim. Biophys. $18,477-482$.

Moor, R.M. \& Trounson, A.O. (1977) Hormonal and follicular factors affecting maturation of sheep oocytes in vitro and their subsequent developmental capacity. J. Reprod. Fert. 49, 101-109.

Moor, R.M. \& Warnes, G.M. (1978) Regulation of oocyte maturation in mammals. In Control of Ovulation, pp. 159-176. Eds D. B. Crighton, G. R. Foxcroft, N. B. Haynes \& G. E. Lamming. Butterworths, London.

Moor, R.M. \& Warnes G.M. (1979) Regulation of meiosis in mammalian oocytes. Br, med. Bull. 35, 99-103.

Overstreet, J.W. \& Hembree, W.C. (1976) Penetration of the zona pellucida of nonliving human oocytes by human spermatozoa in vitro. Fert. Steril. 27, 815-831.

Renou, P., Trounson, A.O., Wood, C. \& Leeton, J.F. (1981) The collection of human oocytes for in vitro fertilization. I. An instrument for maximising oocyte recovery rate. Fert. Steril. 35, 409-412.

Soupart, P. \& Morgenstern, L. (1973) Human sperm capacitation and in vitro fertilization. Fert. Steril. 24, $462-478$.
Soupart, P. \& Strong, P.A. (1974) Ultrasructural observations on human oocytes fertilized in vitro. Fert. Steril. 25, 11-44.

Soupart, P. \& Strong, P.A. (1975) Ultrastructural observations on polyspermic penetration of zona pellucida-free human oocytes inseminated in vitro. Fert. Steril. 26, 523-537.

Steptoe, P.C., Edwards, R.G. \& Purdy, J.M. (1971) Human blastocysts grown in culture. Nature, Lond. 229, 132-133.

Thibault, C. (1977) Are follicular maturation and oocyte maturation independent processes? J. Reprod. Fert. $51,1-15$.

Trounson, A.O., Willadsen, S.M. \& Rowson, L.E.A. (1977) Fertilization and developmental capability of bovine follicular oocytes matured in vitro and in vivo and transferred to the oviducts of the rabbit and cow. J. Reprod. Fert. 51, 321-327.

Trounson, A.O., Rowson, L.E.A. \& Willadsen, S.M. (1978) Non-surgical transfer of bovine embryos. Vet. Rec. 102, 74-75.

Trounson, A.O., Mahadevan, M., Wood, J. \& Leeton, J. (1979) Studies on the deep-freezing and artificial insemination of human semen. In Frozen Human Semen, pp. 173-186. Eds D. Richardson, D. Joyce \& M. Symonds. Royal College of Obstetricians \& Gynaecologists, London.

Trounson, A., Herreros, M., Burger, H. \& Clarke, I. (1980a) The precise detection of ovulation using a rapid radioimmunoassay of urinary LH. Proc. Endocrine Soc. Aust. 23, 73, Abstr.

Trounson, A.O., Leeton, J.F., Wood, C., Webb, J. \& Kovacs, G. (1980b) The investigation of idiopathic infertility by in vitro fertilization. Fert. Steril. 34, $431-438$.

Trounson, A.O., Leeton, J.F., Wood, C., Webb, J. \& Wood, J. (1981) Successful human pregnancies by in vitro fertilization and embryo transfer in the controlled ovulatory cycle. Science, N.Y. 212, 681-682.

Whitten, W.K. \& Dagg, C.P. (1961) Influence of spermatozoa on the cleavage rate of mouse eggs. $J$. exp. Zool. 148, 173-183.

Wood, C., Leeton, J., Talbot, J.Mc. \& Trounson, A.O. (1981a) Technique for collecting mature human oocytes for in vitro fertilization. Br. J. Obstet. Gynaecol. 88, 756-760.

Wood, C., Trounson, A., Leeton, J., Talbot, J.Mc., Buttery, B., Webb, J., Wood, J. \& Jessup, D. (1981b) A clinical assessment of nine pregnancies obtained by in vitro fertilization and embryo transfer. Fert. Steril. 35, 502-508. 